$5-1-2011$

\title{
The Development of the Flute as a Solo Instrument from the Medieval to the Baroque Era
}

Anna J. Reisenweaver

Cedarville University, annajreisenweaver@cedarville.edu

Follow this and additional works at: https://digitalcommons.cedarville.edu/musicalofferings

Part of the Musicology Commons

DigitalCommons@Cedarville provides a publication platform for fully open access journals, which means that all articles are available on the Internet to all users immediately upon publication. However, the opinions and sentiments expressed by the authors of articles published in our journals do not necessarily indicate the endorsement or reflect the views of DigitalCommons@Cedarville, the Centennial Library, or Cedarville University and its employees. The authors are solely responsible for the content of their work. Please address questions to dc@cedarville.edu.

\section{Recommended Citation}

Reisenweaver, Anna J. (2011) "The Development of the Flute as a Solo Instrument from the Medieval to the Baroque Era," Musical Offerings: Vol. 2 : No. 1 , Article 2.

DOI: $10.15385 /$ jmo.2011.2.1.2

Available at: https://digitalcommons.cedarville.edu/musicalofferings/vol2/iss1/2 


\title{
The Development of the Flute as a Solo Instrument from the Medieval to the Baroque Era
}

\section{Document Type}

Article

\begin{abstract}
As one of the oldest instruments known to mankind, the flute is present in some form in nearly every culture and ethnic group in the world. However, in Western music in particular, the flute has taken its place as an important part of musical culture, both as a solo and an ensemble instrument. The flute has also undergone its most significant technological developments in Western musical culture, moving from the bone keyless flutes of the Prehistoric era to the gold and silver instruments known to performers today. During the Renaissance and Baroque periods in particular, however, the flute rose to popularity as a solo instrument and began to evolve into its modern form. New developments in the design and mechanics of the instrument drove this increased interest, which ultimately gave the flute a prominent position in music that has lasted throughout history.
\end{abstract}

\section{Keywords}

Flute, baroque, medieval

\section{Creative Commons License}

c)

This work is licensed under a Creative Commons Attribution-Noncommercial-No Derivative Works 3.0 License. 


\title{
The Development of the Flute as a Solo Instrument from the Medieval to the Baroque Era
}

\author{
Anna Reisenweaver \\ Cedarville University
}

s one of the oldest instruments known to mankind, the flute is present in
some form in nearly every culture and ethnic group in the world.
However, in Western music in particular, the flute has taken its place as an important part of musical culture, both as a solo and an ensemble instrument. The flute has also undergone its most significant technological developments in Western musical culture, moving from the bone keyless flutes of the Prehistoric era to the gold and silver instruments known to performers today. During the Renaissance and Baroque periods in particular, however, the flute ${ }^{1}$ rose to popularity as a solo instrument and began to evolve into its modern form. New developments in the design and mechanics of the instrument drove this increased interest, which ultimately gave the flute a prominent position in music that has lasted throughout history.

When surveying the developments of the flute, it is important to start with the earliest evidences of the instrument in Western music. Unfortunately, the history of the Western flute during the Middle Ages is difficult to trace. There are no surviving transverse, or side-blown, flutes from that period, and "none of [the medieval music] indicates that it should be played by a flute." "In the West the transverse flute fell into oblivion after a modest flowering in prehistoric times and antiquity, to be reintroduced through Byzantine civilization around 1000 [AD].”3 The earliest European depictions of the transverse flute are found in Byzantine art, such as in the frescoes of the Hagia Sophia which include a flutist in a depiction of circus musicians. As the centuries progressed, however, the flute began to have an increased presence in Western European art of the period, suggesting a spreading interest in the instrument. One of the most notable depictions of the transverse flute can be found in an illustration from the Cantigas de Santa Maria manuscripts, which depicts two male players: ${ }^{4}$

\footnotetext{
${ }^{1}$ During the Medieval through Baroque periods, the recorder or end-blown flute was actually more popular and was also titled "flute." The transverse or side-blown flute was clarified as the "transverse" or "German" flute and is the focus of this discussion.

${ }^{2}$ Ardal Powell, The Flute (New Haven: Yale University Press, 2002 ), 7.

${ }^{3}$ Raymond Meylan, The Flute (London: B.T. Batsford Ltd, 1988), 50-52.

${ }^{4}$ Cantigas de Santa Maria, Cantiga 240, "The Cantigas de Santa Maria: All Color Images,” http://www.pbm.com/ lindahl/cantigas/images/all_color.html. Accessed December 14, 2010.
} 


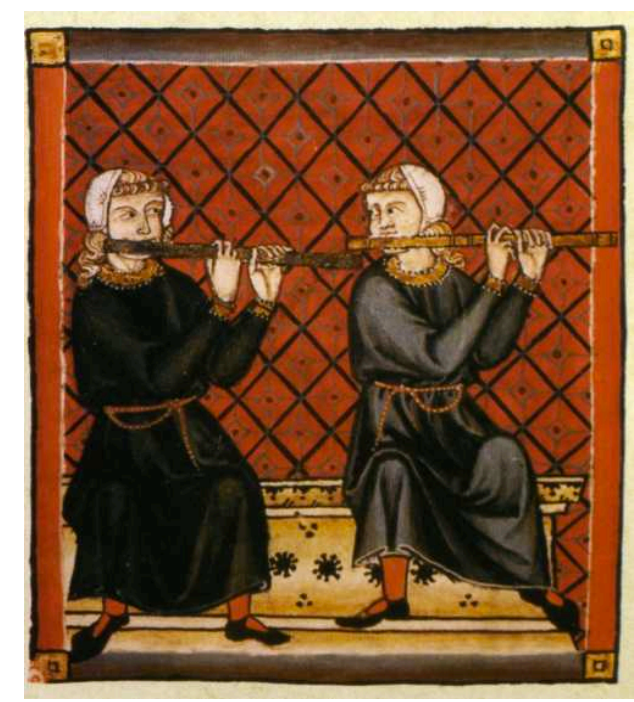

Fig.1. transverse flute, Cantigas de Santa Maria

Because there are no known transverse flutes surviving from the medieval period, it is difficult to determine the sound, structure, and appearance of these instruments. Based on depictions of the flute in medieval art, it would appear that "the only defining feature of the European medieval flute...is that it was held sideways, most commonly to the player's left." ${ }^{5}$ These flutes had no keys and likely had six fingerholes as Renaissance instruments did. They would perhaps have been constructed of bone or wood and would have been in one piece with a cylindrical bore.

The medieval flute appears to have been used in a variety of situations. As evidenced by liturgical art manuscripts such as the Cantigas de Santa Maria, the flute seems to have been used in sacred settings. The instrument also would likely have been used in social settings; however, according to Ardal Powell, "none of the depictions of flutists. . .contain any hint as to what sort of music they played." ${ }^{6}$ Interestingly, the majority of medieval flute iconography depicts the flute in a pastoral setting, often with characters from pagan mythology. The flute is also commonly presented with shepherds, a representation that has been reflected in art and music from Greek culture through modern times. One unique use of the flute proposed by Raymond Meylan is the idea that the flute also functioned as a decoy or hunting instrument. He quotes Johannes Egidius of Zamora's Ars Musica, stating that "hunters use flutes because deer like their sound." According to this theory, one hunter would play a flute to draw the animal out and distract it while another hunter would shoot it. In addition to its use as a sacred, social, and hunting instrument, there is some record of the flute being used in a military context during the late Middle Ages. It is this military use

\footnotetext{
${ }^{5}$ Ardal Powell, The Flute (New Haven: Yale University Press, 2002), 24.

${ }^{6}$ Ibid., 19.

${ }^{7}$ Raymond Meylan, The Flute (London: B.T. Batsford Ltd, 1988), 42.
} 
of the flute that was a major factor contributing to its rise in popularity during the Renaissance.

As European art and culture moved into the Renaissance period, the flute experienced an increase in popularity. According to Powell, this interest in the flute was sparked by the popularity of the Swiss military tactics and also their military music which employed fifes ${ }^{8}$. Be that the case or not, the Renaissance transverse flute, like the medieval flute, is depicted in art and is also mentioned in several musical treatises of the Renaissance. In 1511, Sebastian Virdung's Musica getuscht mentions fifes, and the earliest mention of the transverse flute in a treatise is found in Martin Agricola's Musica instrumentalis deudsch of 1529. The iconography of the flute during that time suggests "that the flute had a twofold usage, as a military instrument and in chamber music," usually found together with other instruments in mixed ensembles." 10

Unlike the medieval flute, there are some surviving Renaissance-era flutes. The earliest flutes had six fingerholes, spaced in two groups of three, and were cylindrical, single-piece tubes. According to Anne Smith, "the player could choose whether to play with the left hand or right hand closer to the embouchure hole," ${ }^{11}$ and it would appear, based on contemporary images of the flute, that it was usually held to the right, in the manner of a modern flute. The flutes of the Renaissance were constructed in three sizes: bass, tenor/altus, and descant. Depending on the size, the flute typically had a range of fifteen to sixteen notes and sounded an octave higher than written, much like the modern piccolo. The design and construction of the flute in three sizes was in keeping with the Guidonian hexachord system, with the bass flute beginning on G gamma ut, the tenor/altus on D sol re, and the descant on A la mi re. "Two of the old modes could begin on D, the lowest note of the tenor/alto flute: Mode I, or the Dorian mode, and Mode VIII, the Hypomixolydian."12 The natural scale of the Renaissance flute was the Dorian mode, and the fingerings for the flute were best in the soft or flat hexachord using B-flat. Because flutes were constructed in three sizes, they were often constructed by the same specialist maker in sets to ensure correct ensemble tuning. Meylan writes that "tuning could be undertaken by the maker. . .yet certain flutes were made in two sections, and could thus be tuned as required."13 The construction of the flute in multiple parts is an important innovation given the fact that pitch during the Renaissance era varied by region, and a two-piece flute would have allowed players to more easily adapt to different pitch levels.

\footnotetext{
${ }^{8}$ Ardal Powell, The Flute (New Haven: Yale University Press, 2002$), 27$.

${ }^{9}$ Anne Smith, "The Renaissance Flute," in John Solum, The Early Flute (Oxford: Clarendon

Press, 1992), 12.

${ }^{10}$ Ibid., 23.

${ }^{11}$ Ibid., 15.

${ }^{12}$ Ardal Powell, "The Hexachords and the Renaissance Flute,” Traverso 11 (January 1999): 1.

${ }^{13}$ Raymond Meylan, The Flute (London: B.T. Batsford, 1988), 81.
} 
These new developments during the Renaissance expanded the performance opportunities of the flute. Because flutes during this period were manufactured in different sizes, they could cover all the parts of a polyphonic work. This innovation led to the popularity, particularly in France, of the four-part flute consort, which typically featured one descant, two tenors, and one bass flute. According to Bernard Thomas, "the earliest surviving music for flutes is to be found in Attaingnant's two chanson collections of 1533:”14,15

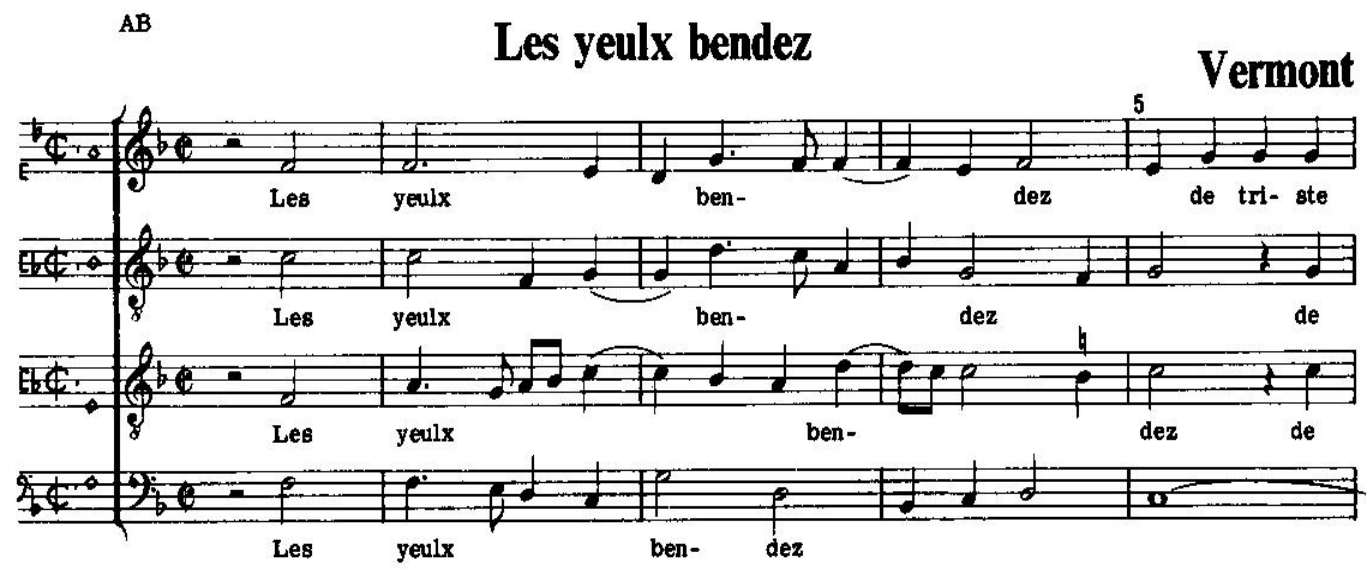

Fig.2. Pierre Attaingnant, “Les yeulx bendez,” mm.1-5.

Although this collection includes the vocal text, the first chanson specifically indicates scoring for flute and recorder consorts. However, composers during the Renaissance era typically did not specify the instrumentation of their works, instead allowing musicians to create mixed ensembles with instruments on hand. As mentioned earlier, art and illustrations from the period indicate that the flute was a part of such ensembles. In light of this, it is apparent that the flute would have been used in a variety of musical styles, particularly in social music such as dances and other instrumental music. Giovanni Bassano's Ricercate, passaggi, et cadentie $^{16}$ is an early example of such polyphonic instrumental music that would be performed on a variety of instruments:

\footnotetext{
${ }^{14}$ Bernard Thomas, “The Renaissance Flute,” Early Music 3 (January 1975): 5. http://www.jstor.org/stable/3125300. Accessed September 30, 2010.

${ }^{15}$ Pierre Attaingnant, Fourteen Chansons (Paris, 1533). Transcribed by Bernard Thomas. (London: Pro Musica Edition), 10.

${ }^{16}$ Giovanni Bassano, "Ricercate, passaggi, et cadentie," http://imslp.info/files/imglnks/usimg/d/d6/IMSLP60626-PMLP124175-003bassano.pdf. Accessed October 3, 2010.
} 


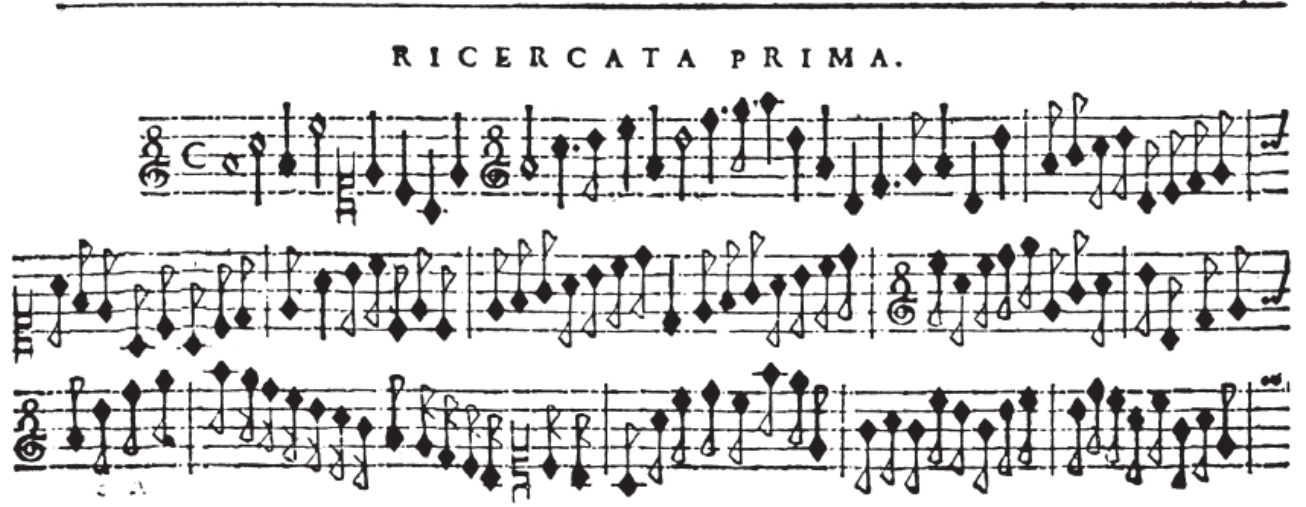

Fig. 3. Giovanni Bassano, "Ricercata prima"

While the flute increased significantly in popularity during the Renaissance period, the Baroque era brought about significant innovations to the instrument which would solidify its importance as a musical instrument. Although "by the late sixteenth century the flute consort's heyday had passed," 17 the flute underwent a variety of changes during the seventeenth and eighteenth centuries, so much so that Powell writes, "if we compare a flute of 1700 with one of a hundred years earlier, all its essential sound-producing mechanisms have changed.”18

During this period, there were several major innovations to the design and construction of the flute. Perhaps the most significant of these was the addition of a seventh hole and key mechanism on the lower end of the flute, which allowed performers to play the enharmonic notes E-flat and D-sharp. As music became more centered around the major and minor modes, the invention of this seventh hole and key allowed flute players to play this new music. Evidence also suggests that Johann Quantz, a popular German flute maker and performer, added a second key "designed to enable the player to distinguish between enharmonic notes such as E-flat and D-sharp." 19 This additional key was considered necessary due to the fact that "in the tuning systems generally used throughout most of the eighteenth century, the flat was played higher than its enharmonic sharp.”20

Another significant improvement to the flute that occurred during the Baroque period was the transition from a cylindrical bore to a conical bore. "In the sixteenth century, [the bore] was cylindrical, whereas in the eighteenth it had become more or less conical, whereby the widest part was always located at the

\footnotetext{
${ }^{17}$ Ardal Powell, The Flute (New Haven: Yale University Press, 2002), 49.

${ }^{18}$ Ibid., 68.

${ }^{19}$ John Solum, The Early Flute (Oxford: Clarendon Press, 1992), 46.

${ }^{20}$ Ibid., 47.
} 
head of the instrument."21 This change in the construction of the flute allowed players to have greater agility, particularly when changing octaves, and gave them a brighter sound, an asset in an era when the individuality of the performer was prized. The conical bore also improved intonation of the upper notes and "effectively flattened the scale; in compensation, the finger-holes were moved closer together." ${ }^{22}$ In addition to developing the conical bore, flute makers also improved intonation by constructing the flute in three pieces, similar to the modern flute, instead of just one. This gave flutists the ability to adapt to different tuning systems, allowing them to play with a wider variety of instruments and ensembles, further increasing their flexibility and, consequently, their popularity.

Although very few Renaissance and medieval flutes have survived, a relatively large number of Baroque flutes have been preserved. These flutes are primarily constructed of some type of wood, typically boxwood, or occasionally metal or ivory. As Marin Mersenne writes in his 1636 musical treatise Harmonie universalle,

Their material can be plum, cherry, or other wood, which can be hollowed out easily, but ordinarily some wood of a beautiful color is chosen, one which takes a beautiful polish so that beauty may accompany the goodness of the instrument, and so that the eyes participate in some fashion with the pleasure of the ear; they are ordinarily made out of box-wood; they are also quite good of crystal, of glass, and of ebony. ${ }^{23}$

The range of these flutes was said to be that of a nineteenth, ${ }^{24}$ and their pitches vary from $A=392$ to $A=415$.

As these new developments began to take hold, the flute again rose in popularity. "These alterations in the design of flutes came as their primary function, along with that of other woodwind instruments, gradually shifted from playing a part in an ensemble of equals to performing the new, more individualistic solo music." 25 Although the flute continued to be used in ensembles for dancing or entertainment, it also became increasingly popular as a melody and solo instrument. This rise in popularity produced the first great flute virtuosos, artists such as Jacques Hotteterre, Jean Loiellet, and Johann Joachim Quantz, whose fame as performers led to an even greater interest in the flute. The flute also became more present in ensembles, with the first known example of a transverse

\footnotetext{
${ }^{21}$ Raymond Meylan, The Flute (London: B.T. Batsford Ltd, 1988), 94.

${ }^{22}$ John Solum, The Early Flute (Oxford: Clarendon Press, 1992), 34.

${ }^{23}$ Marin Mersenne, Harmonie Universalle, trans. by Roger E. Chapman (The Hague: Martinus Nijhoff, 1957): 311.

${ }^{24}$ Ibid., 311.

${ }^{25}$ Ardal Powell, The Flute (New Haven: Yale University Press, 2002), 68.
} 
flute in a baroque orchestra appearing in Jean-Baptiste Lully's Le triomphe de l'amour in $1681 .^{26}$ The flute was used in a variety of ensembles and styles such as sacred concertos, operas, dances, and other instrumental genres.

In addition to the rise in number and quality of flute players, the Baroque period saw an increase in music written specifically for the flute. Sir James Galway writes that "better flutes led to better players, whose performance encouraged more composers to write more pieces." 27 The first Baroque work for the solo transverse flute, published in 1702, was Michel de la Barre's Pièces pour la flute traversiere avec la basse-continue: ${ }^{28}$

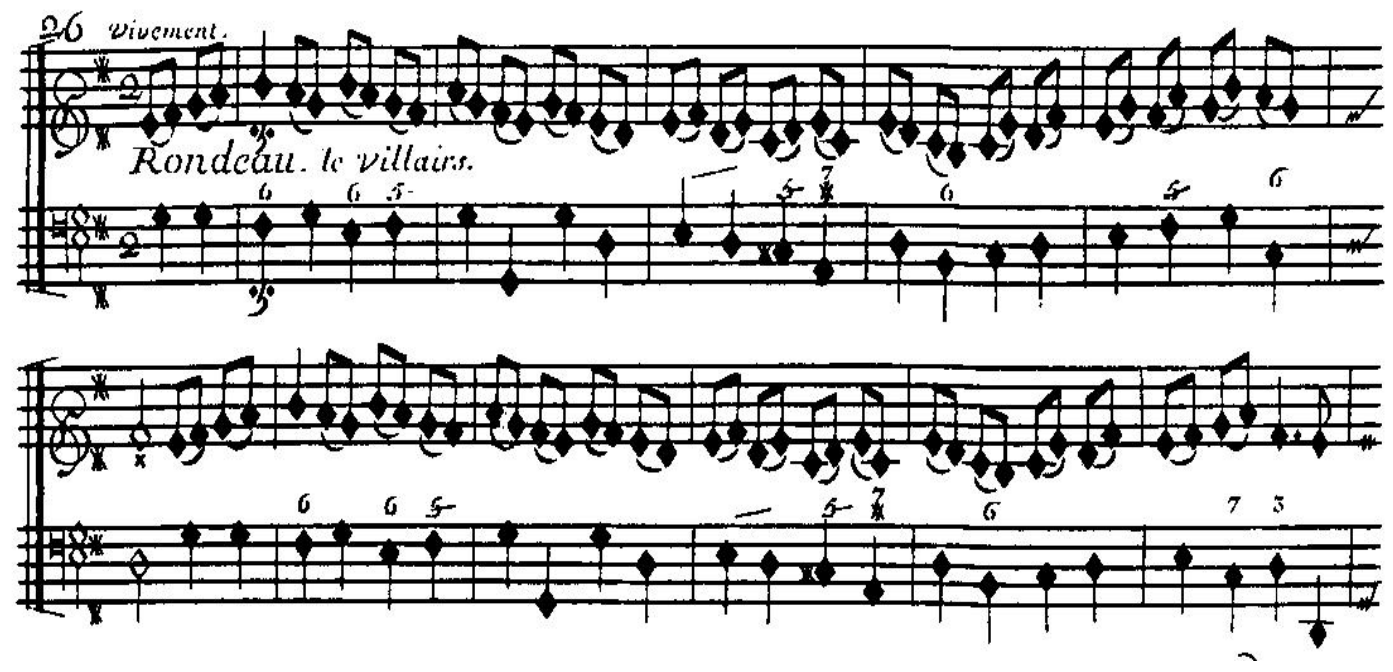

Fig.4. Michel de la Barre, from Pièces pour la flute traversiere

"La Barre intended his pieces...to stimulate a rise in flute-playing standards,",29 which is clearly evident in the increased difficulty and complexity of this music as compared to that of Attaingnant or Bassano. Although non-flutists, such as Attaingnant, wrote for flute, a large number of compositions, pedagogical works, and treatises during the early Baroque period were written by flute virtuosos, most notably Quantz and Hotteterre.

As music progressed into the late Baroque period, an increasing number of nonflutists also began to write solo works for the instrument. Composers such as George Frideric Händel, George Philip Telemann, and Antonio Vivaldi all created works that have become a core part of the standard flute repertory. Telemann's Six Sonatas, Op. 2 were published in 1727, and his Twelve Fantasias for solo

\footnotetext{
${ }^{26}$ John Solum, The Early Flute (Oxford: Clarendon Press, 1992), 35.

27 James Galway, Flute (New York: Schirmer, 1982), 25.

${ }^{28}$ Michel de la Barre, “Deuxieme Livre De Pieces Pour la Flute” (Paris, 1710). Facsimile reproduction by Performer's Facsimiles (New York), 2.

${ }^{29}$ Ardal Powell, The Flute (New Haven: Yale University Press, 2002$), 72$.
} 
flute $^{30}$ followed later in 1732-33. The Fantasias represented, as de la Barre's Pièces did, yet another significant increase in difficulty, demanding greater technical ability from the player.

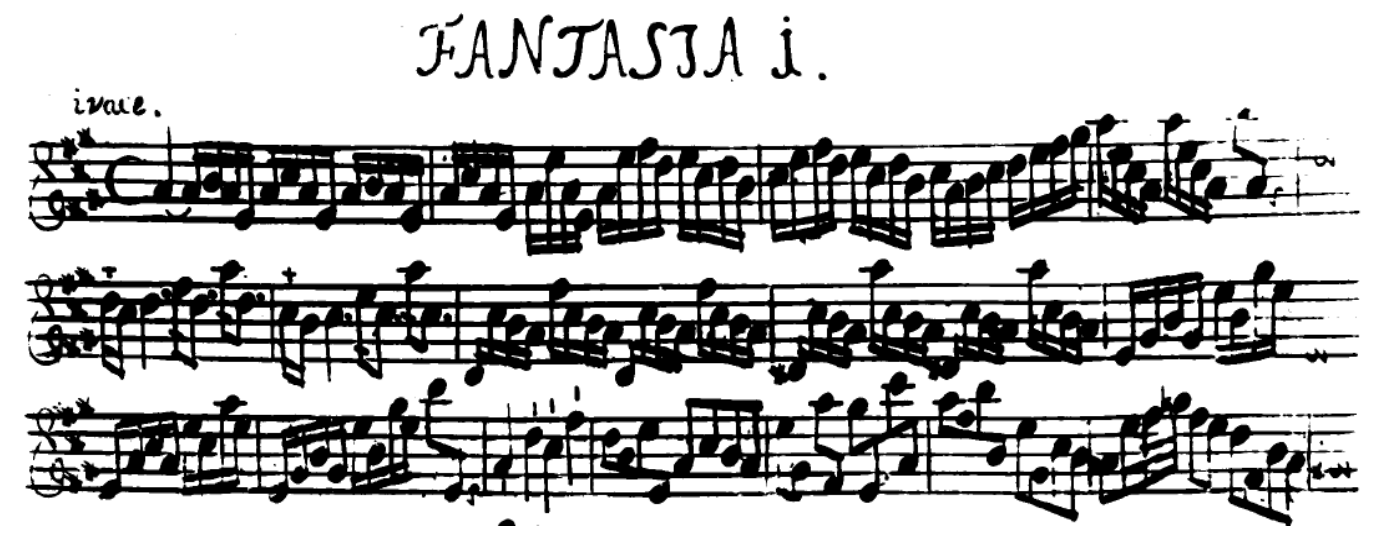

Fig.5. George Philip Telemann, “Fantasia 1,” mm. 1-16

Although Händel, Telemann, and Vivaldi contributed significantly to the flute repertoire, J.S. Bach is perhaps the most influential composer of flute music from this period. His works are among the best known of the Baroque era and are an essential part of the modern flute student's repertory. Powell writes that "Bach seems in fact to have been engaged in experiments with most or all of the musical styles under consideration (temporarily or more lastingly) as suitable for the flute during the entire course of his life" 31 as he "employed the flute in a wider range of tonalities" 32 than previous composers. As a result of innovations such as these, Bach's compositions represent another growth in flute repertoire. The Partita in A minor, BWV 1013, is Bach's first composition for the transverse flute and was published around 1718. Bach also included the flute in the accompaniment of various cantatas and passions, including the famous St. Matthew Passion, BWV 244, and composed at least four sonatas ${ }^{33}$ between 1720-30. His Brandenburg Concerto No.5, BWV $1050,{ }^{34}$ is one of the most important flute compositions of the Baroque era. It is supposedly “Bach's first extant ensemble composition involving the flute. . .[and] as such, it is the first appearance of the flute. . as a concerto instrument." 35 This appears to be one of the earliest surviving

\footnotetext{
${ }^{30}$ Georg Philipp Telemann, "Twelve Fantasias for Solo Flute,” http://imslp.info/files/imglnks/usimg/d/d9/IMSLP32138-PMLP54405Teleman_12_Fantasias for_Traversiere.pdf. Accessed October 20, 2010.

${ }^{31}$ Ardal Powell, "Bach and the Flute: The Players, the Instrument, and the Music," Early Music 23 No. 1 (Feb. 1995): 19. http://www.jstor.org/stable/3137801. Accessed October 4, 2010.

${ }^{32}$ Mary Oleskiewicz, "Bach, Quantz, and the Flute," Traverso 12 (Oct. 2000): 14.

${ }^{33}$ The sonatas in B minor (BWV 1030), A major (BWV 1032), E minor (BWV 1034), and E major (BWV 1035) are confirmed to be written by Bach for the flute. Two other sonatas, the E-flat major (BWV 1031) and the C major (BWV 1033) are commonly attributed to Bach, and the G minor (BWV 1030b) is for an unknown instrument but is frequently performed on flute.

${ }^{34}$ J.S. Bach, Brandenburg Concerto V, BWV 1050, http://216.129.110.22/files/imglnks/usimg/0/08/IMSLP37646-PMLP82083-BachBWV1050.Flute.pdf. Accessed October 20, 2010.

${ }^{35}$ Ardal Powell, The Flute (New Haven: Yale University Press, 2002), 78.
} 
compositions to use the flute in this manner and is yet another illustration of Bach's impact on the flute repertory.

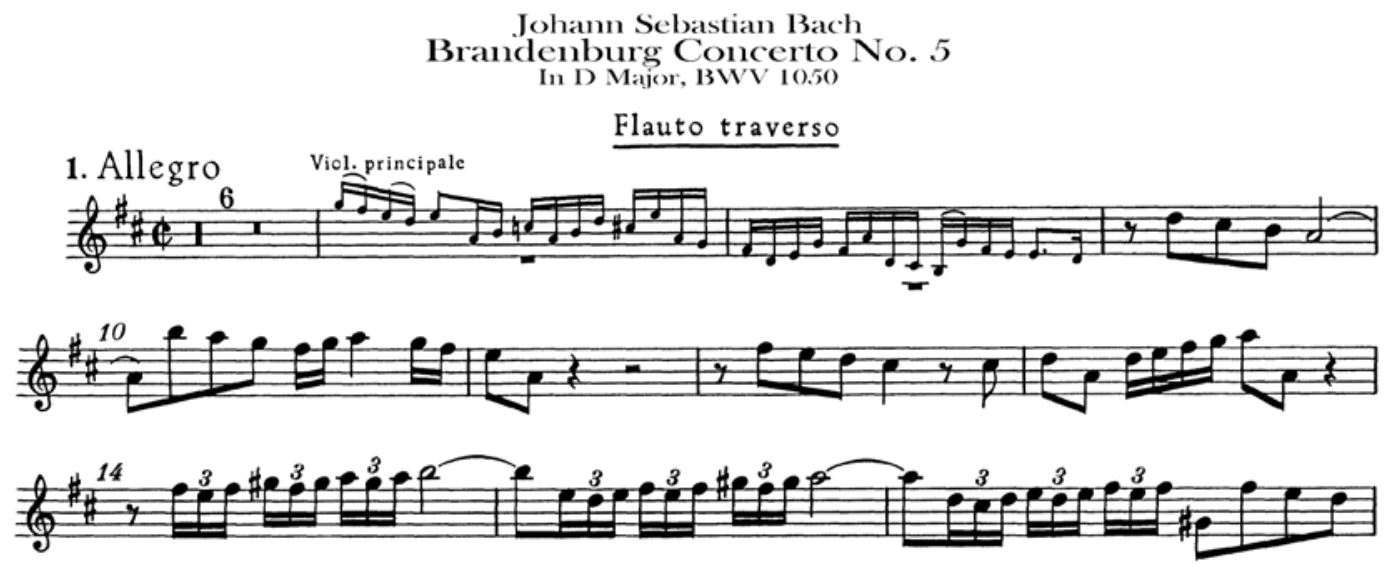

Fig.6. J. S. Bach, Brandenburg Concerto No. 5, “Allegro,” mm. 1-16.

As one of the first compositions to use the flute in a concerto setting, the Brandenburg Concerto has immense historical significance to the flute repertory. Following the publication of Bach's work, other contemporary and later composers, such as Antonio Vivaldi and C.P.E Bach, composed concerti for flute, setting the standard for a vital portion of modern flute repertory.

As a comparison of Bach's Brandenburg Concerto and Attaingnant's Chansons reveals, the literature for flute underwent significant developments from the Renaissance to Baroque periods, a change which is mirrored by the instrument's technological developments during this time. These mechanical and musical innovations of the flute from the medieval through Baroque periods laid the foundation for modern performance and repertory. The change in construction from a keyless, cylindrical instrument to a one-keyed, conical, three-pieced flute would ultimately lead to the creation of the modern flute that Theobald Boehm built in the 1830-40s on the shoulders of Baroque innovations. The developments in the instrument also increased its range and flexibility, allowing flutists to perform a wider variety of music and styles, which in turn caused an increase in compositions specifically for the instrument. As the repertoire began to expand, the flute transitioned from an ensemble to a solo instrument, a change spurred by compositions such as Bach's Brandenburg Concerto No.5. In consequence, the flute now holds a reputation in classical music as an important part of both solo and ensemble repertory. The developments which began during this time period have lasted well into the modern musical culture and have permanently impacted the history of the flute as an instrument. 


\section{Bibliography}

Addington, Christopher. “The Bach Flute.” The Musical Quarterly 71 No. 3 (1985): 264-280. http://www.jstor.org/stable/948156. Accessed October 21, 2010.

Attaingnant, Pierre. Paris, 1533. transcribed by Bernard Thomas. London: Pro Musica Edition.

Bach, J.S. Brandenburg Concerto No.5, BWV 1050. http://216.129.110.22/files/imglnks/usimg/ 0/08/IMSLP37646PMLP82083-Bach-BWV1050.Flute.pdf. Accessed October 20, 2010.

de la Barre, Michel. “Deuxieme Livre De Pieces Pour la Flute.” Paris, 1710. Facsimile reproduction by Performer's Facsimiles. New York.

Bassano, Giovanni. "Ricercate, passaggi, et cadentie.” http://imslp.info/files/imglnks/usimg/d/d6/ IMSLP60626-PMLP124175-003bassano.pdf. Accessed October 3, 2010.

Cantigas de Santa Maria, Cantiga 240, “The Cantigas de Santa Maria: All Color Images,” http://www.pbm.com/ lindahl/cantigas/images/all_color.html. Accessed December 14, 2010.

Evans, Tammy. “The Flute in the Baroque Period.” Flute Talk, May/June 2005.

Galway, James. Flute. New York: Schirmer, 1982.

Mersenne, Marin. Harmonie Universalle. trans. by Roger E. Chapman. The Hague: Martinus Nijhoff, 1957.

Meylan, Raymond. The Flute. London: B.T. Batsford Ltd, 1988.

Oleskiewicz, Mary. “Bach, Quantz, and the Flute.” Traverso 12 (Oct. 2000): 1315.

Powell, Ardal. "Bach and the Flute: The Players, the Instrument, and the Music." Early Music 23, No. 1 (Feb. 1995): 9-29. http://www.jstor.org/stable/3137801. Accessed October 4, 2010.

. The Flute. New Haven: Yale University Press, 2002.

. “The Hexachords and the Renaissance Flute.” Traverso 11 (Jan. 1999): 1-3.

. "Science, Technology and the Art of Flute Making in the Eighteenth Century.” Flutehistory.com. 
http://www.flutehistory.com/Resources/Documents/technology.php3. Accessed December 14, 2010.

Smith, Anne. “The Renaissance Flute.” in John Solum, The Early Flute. Oxford: Clarendon Press, 1992.

Solum, John. The Early Flute. Oxford: Clarendon Press, 1992.

Telemann, Georg Philipp. “Twelve Fantasias for Solo Flute.” http://imslp.info/files/ imglnks/usimg/d/d9/IMSLP32138-PMLP54405Teleman_12_Fantasias_for Traversiere.pdf. Accessed October 20, 2010.

Thomas, Bernard. “The Renaissance Flute.” Early Music 3 (Jan. 1975): 2-10. http://www.jstor.org/stable/3125300. Accessed September 30, 2010. 